\title{
El Museo Arqueológico y Etnológico de Granada
}

El Museo Arqueológico de Granada fue uno de los primeros fundados en España en el año 1879 siguiendo las huellas del Museo Arqueológico Nacional. Con anterioridad, desde 1842, existió el antecedente de un Gabinete de Antigüedades dependiente de la Comisión Provincial de Monumentos.

Tras pasar por diversas ubicaciones, en 1917 se adquirió su actual sede, la Casa de Castril. Enclavada en la carrera del Darro, es uno de los mejores ejemplos de palacio renacentista de Granada. La portada atribuida a un discipulo de Diego de Siloe se terminó de ejecutar en 1539. Presenta una rica decoración plateresca con motivos de la antigüedad clásica y medieval entremezclados. El inmueble es una residencia señorial con amplio zaguán de entrada con escalera gótica de carácter monumental que da acceso a un patio central porticado en torno al cual se disponen, en dos plantas, diversas estancias que se utilizan como las salas de exposición permanente del Museo. El conjunto presenta bellas armaduras, como la que remata el hueco de la escalera principal de acceso del patio a la segunda planta y alfarjes mudéjares de salas y galerias porticadas. Completa el inmueble, por su parte trasera, otro núcleo construido, con jardín, otra galería porticada y un pequeño edificio que alberga la biblioteca y las dependencias administrativas. También la casa contigua, conocida como Casa de Latorre, forma parte de las dependencias museales, ubicándose en ella diversos almacenes, el taller de restauración y el salón de actos.

La exposición museológica se distribuye en siete salas en torno al patio principal: en planta baja la sala I, Paleolítico; sala II, Neolitico y Calcolítico; sala III, Edad del Bronce; y en la planta alta, la sala IV, Colonizaciones y Mundo Ibérico; sala V, Romanización; sala VI, Antigüedad Tardía y sala VII, Andalusí.

En la sala I, Paleolítico, el visitante puede comprender el lento proceso de la evolución humana y su expansión por nuestra tierra durante el periodo denominado Paleolitico, desde hace aproximadamente 1.400 .0000 a los 20.000 años, caracterizados por un modo de vida fundamentalmente cazador-recolector muy influenciado por las cambiantes condiciones climáticas y medioambientales. El contenido de las vitrinas nos muestra los materiales de yacimientos como Cúllar-Baza I, Solana del Zamborino de Fonelas, o la Cueva de la Carigüela de Piñar, con importantes restos del hombre de Neandertal como el frontal de un individuo infantil de unos siete años.

La sala II, Neolítico y Calcolítico, en ella vemos cómo el hombre, por medio de la agricultura, pasa de la vida cazadora-recolectora a la vida sedentaria y productora. Temporalmente abarca desde el 5.500 al 2.100 a. de C. A destacar la aparición de la cerámica y las herramientas en piedra pulimentada. En la provincia de Granada estas poblaciones formarian parte de la llamada "Cultura de las Cuevas". Entre ellas la cueva de los Murciélagos de Albuñol, de la que proceden una serie de materiales muy singulares, como son objetos realizados en esparto trenzado, madera y una diadema de oro. De la Edad del Cobre, piezas expuestas excep- cionales son los dos ídolos antropomorfos del poblado de El Malagón de Cúllar, o la llamada Estela de Fonelas, otra pieza excepcional y única del Museo en la que aparece una figura antropomorfa esquemática.

Sala III, Edad del Bronce. Representada por la llamada cultura de El Argar. Esta se desarrolla entre el 2.100 y el 1.575 a. de C. Los poblados, generalmente, los encontramos en cerros elevados, defendidos con murallas, ubicados en las cercanias de los recursos productivos, en las cabeceras de valles fluviales que ofrecen importantes posibilidades agricolas, o en áreas próximas a recursos minerales. Este sería el caso de los poblados del Cerro de la Encina de Monachil, El Castellón Alto de Galera o de la Terrera del Reloj, de Dehesas de Guadix. Aparece la costumbre de practicar los enterramientos en el interior de las viviendas. De sepulturas halladas bajo el piso de viviendas proceden los objetos expuestos en las vitrinas dedicadas al cerro de la Encina de Monachil, cuesta del Negro de Purullena o cerro de la Virgen de Orce.

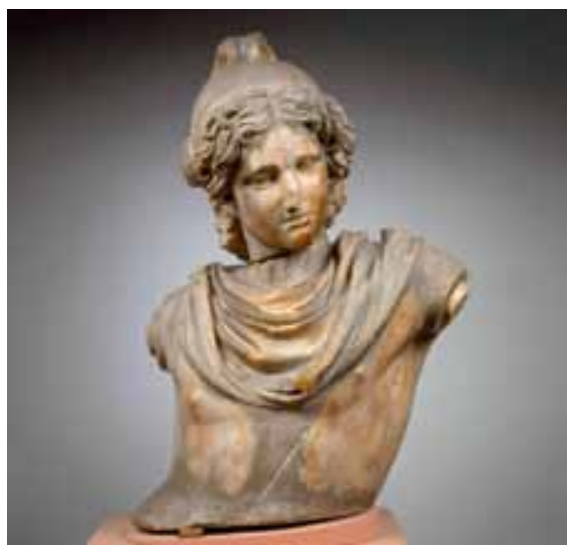

Busto de Ganímedes, estatua romana encontrada en la Alhambra. Fuente: Museo Arqueológico de Granada

Sala IV, Mundo indigena y colonizaciones, en esta sala se observa la transformación paulatina de los asentamientos indigenas motivada por su propia dinámica interna y por las influencias recibidas por su contacto con gentes procedentes del Mediterráneo oriental que se establecen en determinados lugares de la costa mediterránea. De esta época (del siglo VII al siglo I a. de C.), se conocen en Almuñécar dos necrópolis fenico-púnicas, la necrópolis Laurita y Puente de Noy. La excepcionalidad, originalidad, antigüedad, calidad y cantidad de los ajuares procedentes de estas distinguen especialmente la colección expuesta.

La zona ibérica de la provincia se localiza en el interior. En la vega de Granada se encuentran dos importantes oppida (poblados) como llurco (cerro de los Infantes de Pinos Puente) e Ilturir (Albayzin de Granada) origen de la actual ciudad de Granada. En el altiplano se han documentado yacimientos de una gran importancia como Basti del que se conoce sobre todo su necrópolis por el descubrimiento de la Dama de Baza a principio de los años 70 del siglo XX.

Sala V. Romanización. En ella se explica como la politica de conquista y aculturación de los romanos va a modificar las diferentes dinámicas culturales (escritura, religión, cultura material, etc.) de las poblaciones fenicio-púnicas e ibéricas de la provincia de Granada.

En la provincia destacan varias ciudades: Guadix (colonia Iulia Gemella Acci), Almuñécar (Municipium Firmun lulium Sexi), Granada (Municipium Florentinum Iliberritanum) y Pinos Puente (Municipium Ilurconense, lurco). En las ciudades se localizan las edificaciones públicas (foro, basilica, instalaciones para juegos, traída de aguas, etc.) y las residencias de los ciudadanos, asi como los talleres artesanales. La producción agrícola tenía lugar en villae.

En la sala se pueden contemplar materiales de villae como Torralba en Huéscar, loma de Ceres en Molvizar, cortijo del Canal de Albolote, Pago del Fiche de Lecrín y calle Primavera de Granada.

La alfarería está representada por los materiales del alfar romano de Cartuja (Granada).

Destaca, por su calidad y número, la estatuaria romana que integra los fondos de este Museo, representada sobre todo a través de tres piezas muy significativas: el Togado de Periate, la Venus de las termas de Lecrin y el Ganimedes encontrado en la Alhambra.

Las manifestaciones epigráficas se exponen en las galerías de primera y segunda planta del patio.

La sala VI es una pequeña muestra de la Antigüedad Tardía. La decadencia del mundo romano se hace patente a partir del siglo III. El empuje de los pueblos germanos y las luchas internas de los hispanos definen este periodo. Las ciudades van perdiendo peso, manteniéndose tan solo las capitales administrativas. En cuanto al mundo rural se documenta la existencia de importantes villae que presentan elementos suntuarios. Posteriormente se da un proceso de empobrecimiento y de inseguridad del que tan solo se han conservado testimonios de cultura material a través de los ajuares de necrópolis como las de Moraleda de Zafayona, Montefrio, Ventas de Zafarraya, Colomera, Valderrubio y Atarfe.

En la sala VII está presentada la etapa hispanomusulmana. El Museo expone, fundamentalmente, materiales hallados en la ciudad de Medina Elvira (Atarfe). Destacan las lámparas de platillo de la mezquita. También la cerámica "verde y manganeso", tres piezas destacan de este tipo: la jarra de las Liebres, el ataifor del Caballo y el ataifor del Halconero. Del periodo nazari destacan la ballesta de Mecina Bombarón y, especialmente, el astrolabio de bronce fabricación granadina fechado en el año 1481.

En la galeria alta se exponen una selección capiteles tardorromanos, visigodos e hispanomusulmanes.

Isidro Toro Moyano

Maria de los Ángeles González Barroso

Museo Arqueológico y Etnográfico de Granada 